\title{
Article \\ Sp1-Mediated circRNA circHipk2 Regulates Myogenesis by Targeting Ribosomal Protein Rpl7
}

\author{
Junyu Yan ${ }^{1,2,3}$, Yalan Yang ${ }^{1,2,4}$, Xinhao Fan ${ }^{1,2,4}$, Yijie Tang ${ }^{1,2,3,4}$ and Zhonglin Tang 1,2,3,4,5,* \\ 1 Shenzhen Branch, Guangdong Laboratory for Lingnan Modern Agriculture, Agricultural Genomics Institute \\ at Shenzhen, Chinese Academy of Agricultural Sciences, Shenzhen 518124, China; 82101181031@caas.cn (J.Y.); \\ yangyalan@caas.cn (Y.Y.); fanxinhao@caas.cn (X.F.); tangyijie@caas.cn (Y.T.) \\ 2 Genome Analysis Laboratory of the Ministry of Agriculture and Rural Affairs, Agricultural Genomics \\ Institute at Shenzhen, Chinese Academy of Agricultural Sciences, Shenzhen 518124, China \\ 3 Research Centre of Animal Nutritional Genomics, State Key Laboratory of Animal Nutrition, \\ Institute of Animal Sciences, Chinese Academy of Agricultural Sciences, Shenzhen 518124, China \\ 4 Kunpeng Institute of Modern Agriculture at Foshan, Foshan 528226, China \\ 5 GuangXi Engineering Centre for Resource Development of Bama Xiang Pig, Bama 547500, China \\ * Correspondence: tangzhonglin@caas.cn
}

check for updates

Citation: Yan, J.; Yang, Y.; Fan, X.; Tang, Y.; Tang, Z. Sp1-Mediated circRNA circHipk2 Regulates Myogenesis by Targeting Ribosomal Protein Rpl7. Genes 2021, 12, 696. https://doi.org/10.3390/ genes 12050696

Academic Editor: Christos K. Kontos

Received: 14 April 2021

Accepted: 3 May 2021

Published: 8 May 2021

Publisher's Note: MDPI stays neutral with regard to jurisdictional claims in published maps and institutional affiliations.

Copyright: (c) 2021 by the authors. Licensee MDPI, Basel, Switzerland. This article is an open access article distributed under the terms and conditions of the Creative Commons Attribution (CC BY) license (https:/ / creativecommons.org/licenses/by/ $4.0 /)$.
Abstract: Circular RNAs (circRNAs) represent a class of covalently closed single-stranded RNA molecules that are emerging as essential regulators of various biological processes. The circRNA circHipk2 originates from exon 2 of the Hipk2 gene in mice and was reported to be involved in acute promyelocytic leukemia and myocardial injury. However, the functions and mechanisms of circHipk2 in myogenesis are largely unknown. Here, to deepen our knowledge about the role of circHipk2, we studied the expression and function of circHipk2 during skeletal myogenesis. We found that circHipk2 was mostly distributed in the cytoplasm, and dynamically and differentially expressed in various myogenesis systems in vitro and in vivo. Functionally, overexpression of circHipk2 inhibited myoblast proliferation and promoted myotube formation in $\mathrm{C} 2 \mathrm{C} 12$ cells, whereas the opposite effects were observed after circHipk2 knockdown. Mechanistically, circHipk2 could directly bind to ribosomal protein Rpl7, an essential 60S preribosomal assembly factor, to inhibit ribosome translation. In addition, we verified that transcription factor $S p 1$ directly bound to the promoter of circHipk2 and affected the expression of Hipk2 and circHipk2 in C2C12 myoblasts. Collectively, these findings identify circHipk2 as a candidate circRNA regulating ribosome biogenesis and myogenesis proliferation and differentiation.

Keywords: circRNA; circHipk2; Rpl7; myogenesis; skeletal muscle; Sp1

\section{Introduction}

Myogenesis plays important roles in skeletal muscle regeneration and growth [1,2]. It is a multistep process, including myoblast proliferation, myocyte differentiation, fusion of multinuclear myotubes with the central nucleus, and further muscle fiber maturation [3,4]. It is well known that myogenesis is regulated by myogenic regulatory factors (MRFs), such as the muscle bHLH proteins Myf5, myogenin (MyoG), MyoD and MRF4, and the MEF2 family members $[2,5,6]$. Recently, increasing evidence suggested that other RNA types, including microRNAs (miRNAs), long non-coding RNAs (lncRNAs), and circular RNAs (circRNAs), play important roles during myogenesis in mammals [7,8]. For example, miR-1 and $m i R-133$ are well-known myomiRs, $m i R-1$ promotes myogenesis by targeting histone deacetylase 4 (HDAC4), and miR-133 enhances myoblast proliferation by repressing serum response factor $(S R F)$ [9]. LncRNA linc-RAM regulates the expression of myogenic genes by binding to $M y o D$, thus enhancing myogenic differentiation [10]. However, compared to miRNAs and lncRNAs, studies of circRNAs in myogenesis are still limited.

As a novel type of ncRNA derived from exons, introns, or intergenic regions, circRNAs have a covalently closed continuous loop, are generally expressed at low levels, and often 
exhibit cell type-specific and tissue-specific patterns [11-13]. Recently, many studies have revealed the crucial functions of circRNAs in myogenesis as a miRNA sponge [14,15]. For example, circLMO7 regulates myoblast differentiation and survival by sponging miR-378a-3p [15]. circRILPL1 acts as a miR-145 sponge to facilitate the proliferation and differentiation of myoblasts via the IGF1R/PI3K/AKT signaling pathway [16]. In addition, circZNF609 and circFAM188B can be combined with polysomes for translation, thereby regulating myoblast proliferation $[17,18]$. However, little circRNAs functioning as protein sponges have been discovered in myogenesis, and need to be systematically explored.

The circular RNA circHipk2 is reported to be a regulator of many cellular processes, such as proliferation, apoptosis, and autophagy [19-21]. The host gene of circHipk2, serine/threonine kinase homeodomain-interacting protein kinase 2 (Hipk2), is widely involved in multiple biological processes, including cell proliferation, cell differentiation, and apoptosis [22-24]. In myoblasts, the Hipk2 gene is involved in cell cycle regulation, and functions alternatively as a corepressor that inhibits myocyte enhancer factor 2 (MEF2)-dependent gene expression $[25,26]$. In our previous work, we found that circHipk 2 was upregulated in differentiated myotubes compared to proliferating myoblasts in $\mathrm{C} 2 \mathrm{C} 12$ myoblast cells. However, the function and mechanism of circHipk2 in myogenesis are still unknown. In this study, we profiled the temporal expression patterns of circHipk2 in vitro and in vivo, and analyzed the function and mechanism of circHipk2 in myogenesis. The results revealed that circHipk2 inhibited myoblast proliferation and promoted differentiation by targeting ribosomal protein L7 (Rpl7), a ribosomal protein that is a component of the 60S subunit. Our recent study suggested that overexpression of transcription factor Sp1 promoted differentiation and repressed proliferation in $\mathrm{C} 2 \mathrm{C} 12$ myoblasts [27]. In this study, we verified that $S p 1$ could directly bind to the promoter of circHipk2 and thus affect its transcription activity. Our findings indicated that circHipk2 may exert regulatory functions in skeletal muscle development.

\section{Materials and Methods}

\subsection{Cell Isolation and Culture}

HEK293T and C2C12 cells were cultured in Gibco Dulbecco's modified Eagle medium (DMEM) (Gibco, Co Dublin, Ireland) supplemented with 10\% FBS in a humidified incubator with $5 \% \mathrm{CO}_{2}$ at $37^{\circ} \mathrm{C}$. To induce myogenic differentiation, $\mathrm{C} 2 \mathrm{C} 12$ cells were incubated in DMEM supplemented with $2 \%$ heat-inactivated horse serum (Gibco).

\subsection{Plasmid Construction and RNA Interference}

The promoter of Hipk2 was subcloned into the pGL3-Basic vector (Promega, Madison, WI, USA). To construct the overexpression vectors, the full-length sequence of mouse circHipk2 and Sp1 were cloned into the pLC5-circ vector and pcDNA3.1 vector, respectively (Geenseed Biotech, Guangzhou, China). The siRNAs of these genes were synthesized in Ribobio Biotech (Guangzhou, China), and their sequences are listed in Table S1.

\section{3. circRNA Pull-Down Assay}

A pLC5-circHipk2-Flag vector and pLC5-circHipk2 vector were constructed by Geenseed Biotech (Guangzhou, China). Cellular lysates from C2C12 myoblasts with a transfecting pLC5-circHipk2-Flag vector or pLC5-circHipk2 were divided into an input group and pulldown group, in which the pull-down group was used for circHipk2 pull-down, and the protein level of RpL7 was normalized to GAPDH (38 kDa) in the input group. Briefly, streptavidin beads were prewashed and blocked according to the manufacturer's instructions. Cellular lysates (pull-down group) were incubated with $100 \mu \mathrm{L}$ streptavidin beads overnight at $4{ }^{\circ} \mathrm{C}$. circHipk2-Flag-bound proteins were eluted with $100 \mu \mathrm{L}$ urea buffer $(2 \mathrm{M}$ urea and $50 \mathrm{mM}$ Tris ( $\mathrm{pH} 7.5)$ ) supplemented with $1 \mathrm{mM}$ dithiothreitol and $5 \mu \mathrm{g} / \mu \mathrm{L}$ trypsin and LysC. After alkylation with $5 \mathrm{mM}$ iodoacetic acid (IAA), proteins were proteolytically digested with trypsin and LysC for $24 \mathrm{~h}$. Peptides were acidified, loaded on SDB-RPS 
material and eluted and dried. Peptides were resuspended in 2\% acetonitrile (ACN) and $0.1 \%$ trifluoroacetic acid (TFA), then MS analyses were performed.

\subsection{Cell Proliferation Assay}

Cell proliferation was determined by a $5^{\prime}$ ethynyl-2'-deoxyuridine (EdU) incorporation assay kit (Ribobio) and Cell Counting Kit-8 (CCK-8) reagent (Dojindo). The C2C12 cells were cultured in GM containing EdU for $2 \mathrm{~h}$. Ten microliters of CCK- 8 were added to each well of a 96-well plate containing cells and incubated at $37^{\circ} \mathrm{C}$ for $45 \mathrm{~min}$.

\subsection{RNA Preparation, RT-PCR, and RT-qPCR}

Total RNA was extracted from skeletal muscles and cells using TRIzol reagent (Invitrogen, Carlsbad, CA, USA) according to the manufacturer's instructions. For RNase $\mathrm{R}$ treatment, total RNA $(2 \mu \mathrm{g})$ was cultivated for $30 \mathrm{~min}$ at $37^{\circ} \mathrm{C}$ with or without $3 \mathrm{U} / \mathrm{mg}$ of RNase R (Epicentre). RNAs from the nucleus and cytoplasm of C2C12 myoblasts were separated using a Cytoplasmic and Nuclear RNA Purification Kit (Norgen, Thorold, ON, Canada) following the manufacturer's instructions. cDNAs were prepared using reverse transcriptase (Thermo Fisher Scientific, Waltham, MA, USA). Oligo(dT) primers were used for coding genes and random primers were used for circRNAs. Reverse transcription PCR (RT-PCR) analysis was performed to detect the existence of circHipk2 in cDNAs and genomic DNAs using divergent primers by KOD-Plus-Neo (Toyobo, Osaka, Japan). The following three-step protocol was used: one cycle at $94^{\circ} \mathrm{C}$ for $2 \mathrm{~min}$, followed by 34 cycles at $98{ }^{\circ} \mathrm{C}$ for $10 \mathrm{~s}, 60^{\circ} \mathrm{C}$ for $30 \mathrm{~s}$, and $68^{\circ} \mathrm{C}$ for $30 \mathrm{~s}$. Finally, $25 \mu \mathrm{L}$ of the total PCR volume were used according to the manual protocol. Analysis of gene expression was performed with SYBR Green Master Mix (ABI) by quantitative real-time PCR (RT-qPCR). RT-qPCR data were analyzed using the $\Delta \Delta \mathrm{Ct}$ method as in our previous report [27]. The primer sequences used in the present study are listed in Table S1.

\subsection{Western Blotting}

The total proteins from $\mathrm{C} 2 \mathrm{C} 12$ cells were lysed in RIPA lysis buffer supplemented with a protease inhibitor cocktail (Roche, Mannheim, Germany). The membranes were blocked with $5 \%$ BSA for $1.5 \mathrm{~h}$ at room temperature, and subsequently probed with primary antibodies overnight at $4{ }^{\circ} \mathrm{C}$. The following dilutions were used for each antibody: myogenin (1:1000; Proteintech, Rosemont, IL, USA), MyHC1 (1:1000; Dshb, New Delhim, India), GAPDH (1:1000; Proteintech), PCNA (1:1000; Proteintech), cyclin E1 (1:1000; Proteintech), and Rpl7 (1:1000; Abcam, Cambridge, MA, USA). The membranes were then washed with PBS-Tween and incubated for $30 \mathrm{~min}$ with horseradish peroxidase-conjugated secondary antibodies (Proteintech). Protein bands were detected after treatment with SuperSignal West Femto agent (Thermo Scientific).

\subsection{RNA Fluorescence In Situ Hybridization Assay (RNA-FISH)}

The RNA-FISH assay was performed in $\mathrm{C} 2 \mathrm{C} 12$ myoblasts following the manufacturer's instructions (GEFAN). The probe sequence for circHipk2 is $5^{\prime}$-CGGTAGTATCTGGAT TGCAAGTACGTAGAGCAGACAGCTTTGGAC- $3^{\prime}$, and that for $R p l 7$ is $5^{\prime}$-TCCTTGCCTTT CGAAGTGTCTTCAGGGCAAACTTCTTCCTCAGGC- $3^{\prime}$. Briefly, cells were seeded onto a cover-glass in 6-well plates, cultured to $70-80 \%$ confluence, and fixed. Following treatment with $0.1 \%$ Triton X-100, cells were incubated with $20 \mathrm{mg} / \mathrm{mL}$ probes overnight at $37^{\circ} \mathrm{C}$. Nuclei was counterstained with DAPI. Images were acquired using an FV1200 laser confocal microscope (Olympus, Tokyo, Japan).

\subsection{Immunostaining Staining}

C2C12 myoblasts were fixed on coverslips with $4 \%$ paraformaldehyde for $10 \mathrm{~min}$, washed with PBS, and treated with $0.3 \%$ Triton X-100/PBS at room temperature for a further $20 \mathrm{~min}$. Cells were rinsed with PBS twice and blocked in 5\% goat serum including Tris-buffered saline buffer for one hour at room temperature, followed by incubation with 
primary antibodies for $2 \mathrm{~h}$. Sections or cells were then washed in PBS and incubated with secondary antibodies for $1 \mathrm{~h}$. Primary and secondary antibodies were anti-MyHC1 (1:100, DSHB) and Alexa Fluor 594 goat anti-mouse IgG (1:400, Proteintech), respectively.

\subsection{RNA Immunoprecipitation (RIP)}

A Magna RIP RNA-Binding Protein Immunoprecipitation Kit (BersinBio) was used to determine the interaction between circHipk2 and Rp17. Antibodies used for the RIP assay included anti-Rpl7 and control IgG (Millipore, Billerica, MA, USA). The RNA/protein complex was recovered using protein $G$ Dynabeads ${ }^{\mathrm{TM}}$ and washed with RIPA buffer several times. Following digestion with proteinase K, RNA was recovered using TRIzol and analyzed by RT-qPCR.

\subsection{Chromatin Immunoprecipitation (ChIP)}

A ChIP assay was performed using a ChIP kit (EMD Millipore Corporation, Billerica, MA, USA) following the manufacturer's instructions as previously described [27]. Briefly, the crosslinking reaction was terminated by glycine in Sp1 overexpression C2C12 cells treated with $1 \%$ formaldehyde. Next, samples were lysed for $10 \mathrm{~min}$ in lysis buffer on ice, and sonicated to an average length of 200-1000 bp. The anti-Rpl7 antibody (Abcam) was added to form the antibody-target protein-DNA complex, and protein A-Sepharose beads were used to immunoprecipitate the complex. After washing and reversing the crosslinks, precipitated DNA was amplified by RT-PCR. Primer sequences are provided in Table S1.

\subsection{Statistical Analysis}

Statistical analysis was performed using the SPSS 13.0 software package. Each data value represents the mean \pm S.D./S.E.M. for 3-5 separate experiments. The significance (such as $p<0.05$ ) of differences between the experimental variables was determined using Welch's $t$-test.

\section{Results}

\section{1. circHipk2 Is a Candidate Regulator of Myogenesis}

In our previous study, several differentially expressed circRNAs were identified by microarray analysis during myoblast differentiation. Among them, circHipk2 caught our attention, since circHipk2 was more highly expressed in differentiated myotubes compared to proliferating myoblasts in $\mathrm{C} 2 \mathrm{C} 12$ cells, and its host gene Hipk2 was reported to be time-dependently expressed in skeletal muscle [28]. Sequence analysis suggested that circHipk2 was a single exonic circRNA generated by exon 2 of the linear Hipk 2 sequence in mice. The junction sequence of circHipk2 was confirmed by divergent primers, then validated by Sanger sequencing (Figure 1a). RT-PCR results showed that circHipk2 was only detected in cDNA, thus ruling out the existence of circHipk2 in genomic DNA (gDNA), whereas the convergent primers amplified Hipk2 from both cDNA and gDNA (Figure 1b). In addition, we found that circHipk2 was resistant to RNase R digestion, whereas the linear Hipk2 transcript was digested by RNase R (Figure 1c).

We next examined the temporal expression patterns of circHipk2 in vitro and in vivo. The age-dependent decrease in the expression of circHipk2 was found in the mouse hind leg muscles during postnatal development (Figure 1d). Using the cardiotoxin (CTX)-induced skeletal muscle damage and regeneration model, we analyzed the expression of circHipk2 during skeletal muscle regeneration and found that circHipk2 was highly expressed $2 \mathrm{~d}$ post injury and subsequently decreased in expression thereafter (Figure 1e). Further investigation confirmed that circHipk2 was expressed at low levels in the proliferating myoblasts but at high levels during differentiation (Figure 1f). Expression patterns of circHipk2 were different from that of the linear Hipk2 transcript, indicating that circHipk2 might function independently of Hipk2 (Figure S1). Then, we determined the subcellular localization of circHipk2. Based on RNA-FISH (Figure 1g) and chromatin fractionation (Figure 1h), we found that circHipk2 was mostly distributed in the cytoplasm, suggesting 
that circHipk2 might play a role in post-transcriptional regulation. Taken together, these data indicate that circHipk2 potentially is involved in myogenesis and skeletal muscle development.

(a)

Chromosome 6: 38,671,325-38,853,099 reverse stran
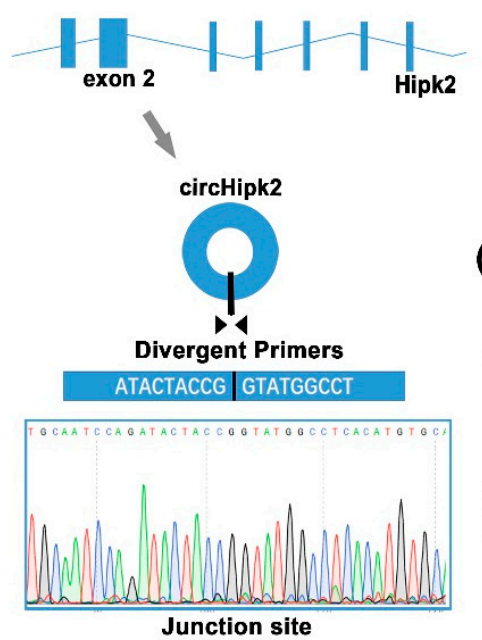

(b)

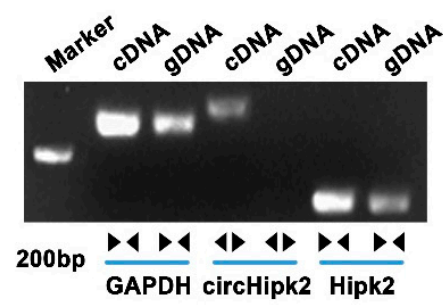

(c)

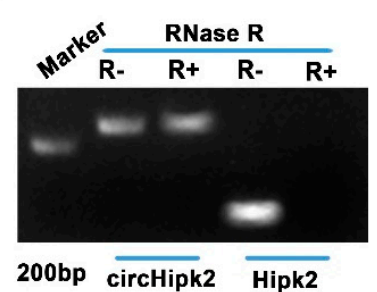

(e)

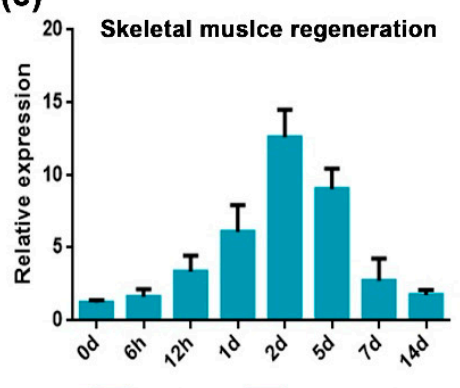

(g)

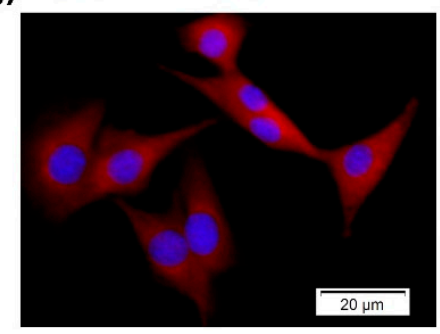

(d)
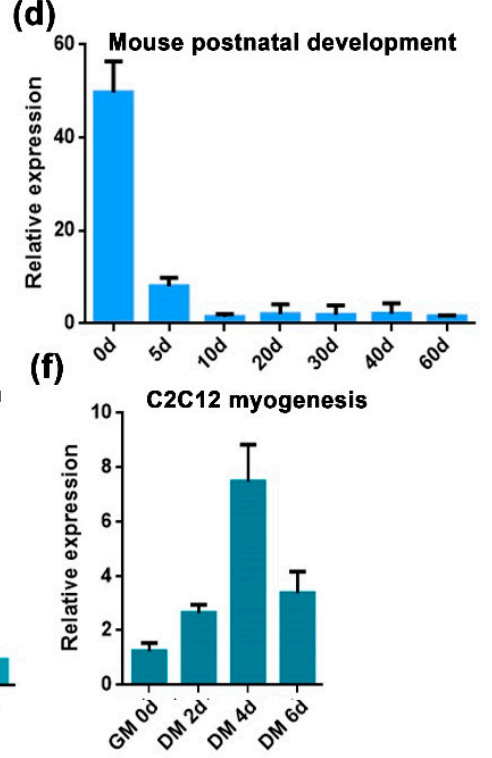

(h)

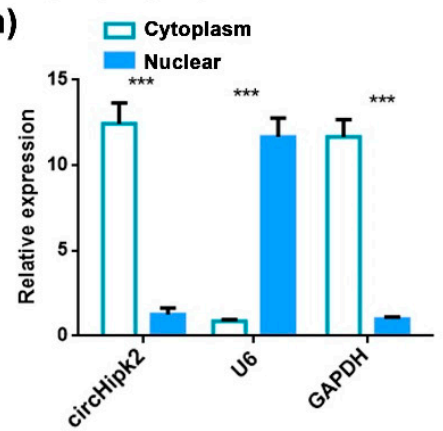

Figure 1. circHipk2 is a candidate regulator of myogenesis and skeletal muscle regeneration. (a) Schematic illustration of circHipk2 formation via the circularization of exon 2 in Hipk2 gene. The back-splice junction sequences and RT-PCR product of circHipk 2 were validated by Sanger sequencing. (b) RT-PCR was performed to detect the existence of circHipk2 and Hipk2 from cDNA and gDNA in C2C12 myoblasts using the divergent and convergent primers. (c) RT-PCR was conducted to determine circHipk2 in C2C12 myoblasts treated with RNase R. (d-f) RT-qPCR analysis of the expression of circHipk2 during postnatal development in the hind leg muscles of C57BL/6 mice (d), during CTX-induced TA muscle regeneration (e) and during $\mathrm{C} 2 \mathrm{C} 12$ myogenesis (f). (g) RNA-FISH was performed to determine circHipk2 subcellular localization in $\mathrm{C} 2 \mathrm{C} 12$ myoblasts. Blue indicates nuclei stained with DAPI; red indicates the RNA probe that recognizes circHipk2. The scale is $20 \mu \mathrm{m}$. (h) Verification of circHipk2 localization by subcellular fractionation. The error bars depict the mean \pm S.D. of samples from 3 individuals. ${ }^{* * *} p<0.001$.

\section{2. circHipk2 Represses Myoblast Proliferation but Promotes Differentiation}

To explore the function of circHipk2 in myogenesis, we first investigated whether circHipk2 regulated C2C12 myoblast proliferation. We constructed a circHipk2 overexpression (circHipk2-OV) vector (Figure S2A) and designed two small interfering RNAs (si-circHipk2-01 and si-circHipk2-02) to target the back-splicing junction of circHipk2. After transfecting them into $\mathrm{C} 2 \mathrm{C} 12$ myoblasts, the si-circHipk2-02 fragment showed higher silencing efficiency than the si-circHipk2-01 fragment, and was chosen for subsequent analysis (Figure 2a). We observed that knockdown of circHipk2 by si-circHipk2-02 significantly upregulated the expression of proliferation markers (Ki67, PCNA, cyclin E1, and $C D K 4$ ) at both mRNA (Figure 2a) and protein levels (Figure 2b), whereas overexpression of circHipk2 significantly decreased the expression of these genes (Figure S2B). Based on 
the EdU incorporation assay and CCK-8 assay, we observed that knockdown of circHipk2 significantly increased cell proliferation activities in C2C12 myoblasts (Figure 2c,d). In contrast, overexpression of circHipk2 caused the opposite effects (Figure S2B,C).

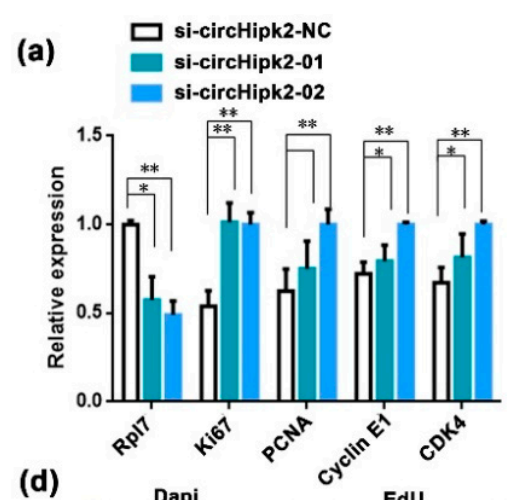

(1)
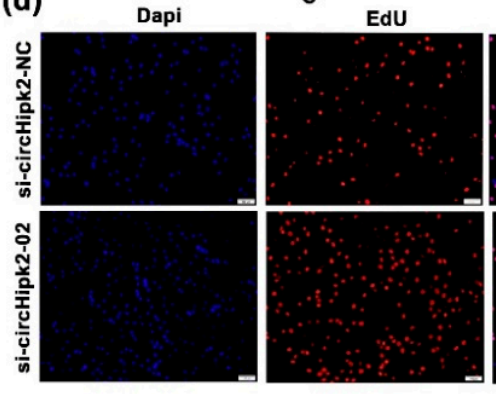

(g) (b)

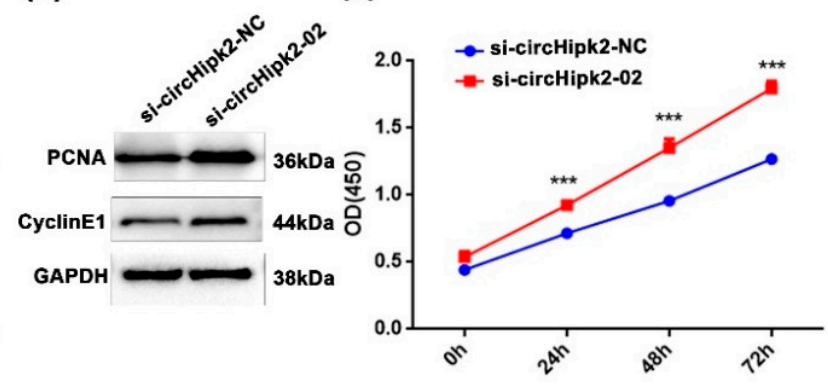

(e)

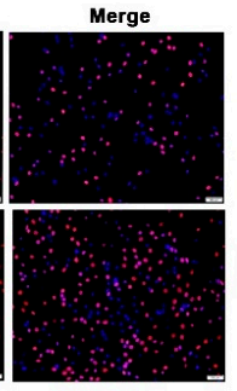

(c)

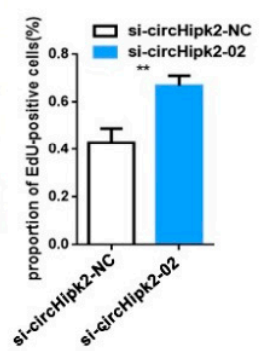

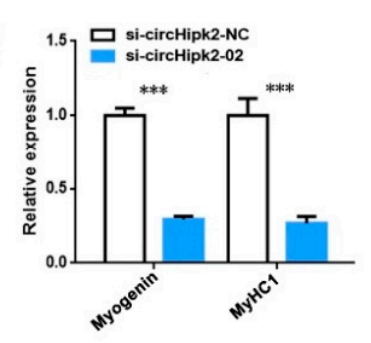
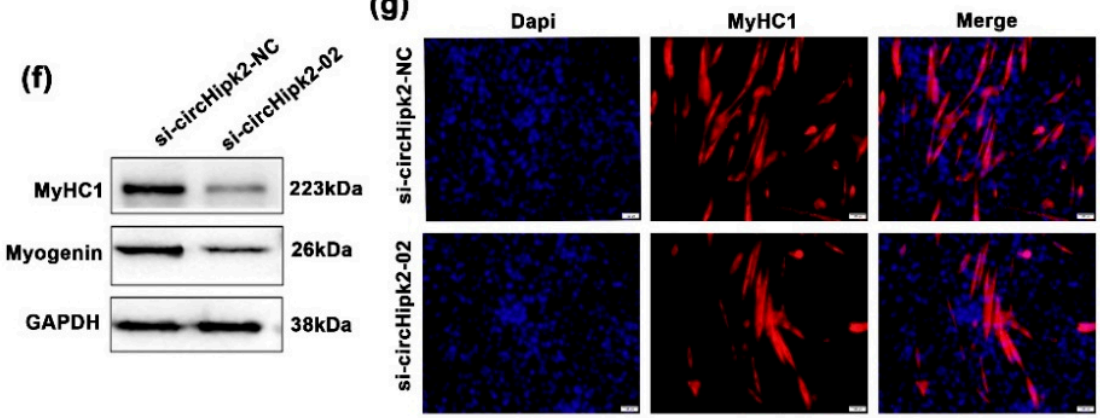

Figure 2. circHipk2 represses $\mathrm{C} 2 \mathrm{C} 12$ myoblast proliferation but promotes differentiation. $(\mathbf{a}, \mathbf{b})$ The expression of proliferation and cell cycle markers was quantitated by RT-qPCR (a) and Western blotting (b) in C2C12 myoblasts. Data are presented as the mean \pm S.D. $N=3$ per group. ${ }^{*} p<0.05,{ }^{* *} p<0.01$ and ${ }^{* * *} p<0.001$. (c) Cell proliferation was assessed using the CCK-8 assay after transfection with si-circHipk2-02 or si-circHipk2-NC. (d) EdU assay to assess cell proliferation after transfection with si-circHipk2-02 or si-circHipk2-NC in C2C12 myoblasts. Cell proliferation indices were assessed after treatment with EdU and counted using ImageJ. EdU staining (red) for positive cells; DAPI staining (blue) for cell nuclei. The scale bars represent $100 \mu \mathrm{m}$. (e,f) The expression levels of myogenin and MyHC1 were detected by RT-qPCR (e) and Western blotting (f) after transfection with si-circHipk2-02 or si-circHipk2-NC in C2C12 myoblasts. (g) Immunofluorescence analysis of MyHC1 cells (red) after transfection with si-circHipk2-02 or si-circHipk2-NC in C2C12 myoblasts. The scale bars represent $100 \mu \mathrm{m}$.

Next, we investigated the role of circHipk2 on myoblast differentiation, and found circHipk2 prevented the expression of the myoblast determination factors (myogenin and MyHC1) at both mRNA (Figure 2e) and protein levels (Figure 2f), whereas overexpression of circHipk2 increased the expression of these differentiation markers (Figure S2D). The immunofluorescence assay suggested that knockdown of circHipk2 dramatically blocked myotube formation when compared with the control group (Figure 2g), whereas overexpression of circHipk2 promoted myotube formation (Figure S2E). Collectively, these results indicated that circHipk2 repressed myoblast proliferation and promoted differentiation in C2C12 cells. 


\section{3. circHipk2 Directly Binds to Ribosomal Protein Rpl7}

To identify the downstream targets of circHipk2 in myogenesis, we next performed a proteomic screen to identify potential circHipk2-binding proteins (Figure 3a). We generated C2C12 myoblasts with stable overexpression of pLC5-circHipk2-Flag engineered to contain RNA hairpin BoxB sequences (Figure 3a), this allowed the capture of circHipk2-binding proteins in cellular lysates via high-affinity interaction of the BoxB RNA hairpin with bacteriophage $\lambda$ transcriptional antiterminator protein $\mathrm{N}$ ( $\lambda \mathrm{N}$-peptide) coupled to beads [29,30]. Then, we used $2 \mu \mathrm{g}$ of precipitated protein for label-free mass spectrometric analyses. A total of 49 proteins were identified to be significantly enriched in extracts from pLC5-circHipk2-Flag C2C12 myoblasts (Table S2). Gene ontology (GO) and KEGG pathway enrichment analysis revealed that the majority of target proteins were involved in ribosome biogenesis and assembly $(28 \%)$ (Figure S3A,B), suggesting that circHipk2 may play a crucial role in these important cellular processes.

(a)

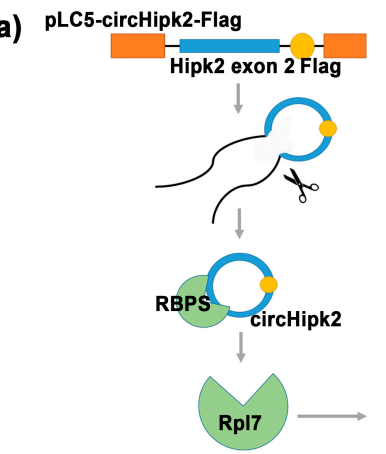

(b)

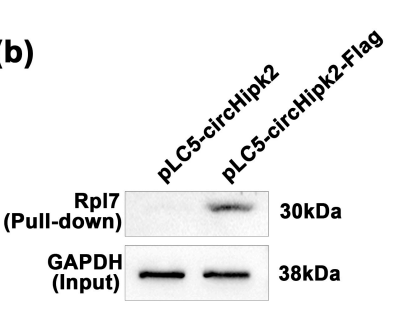

(e)

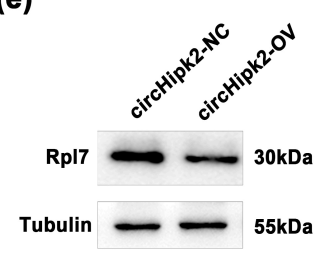

(f)

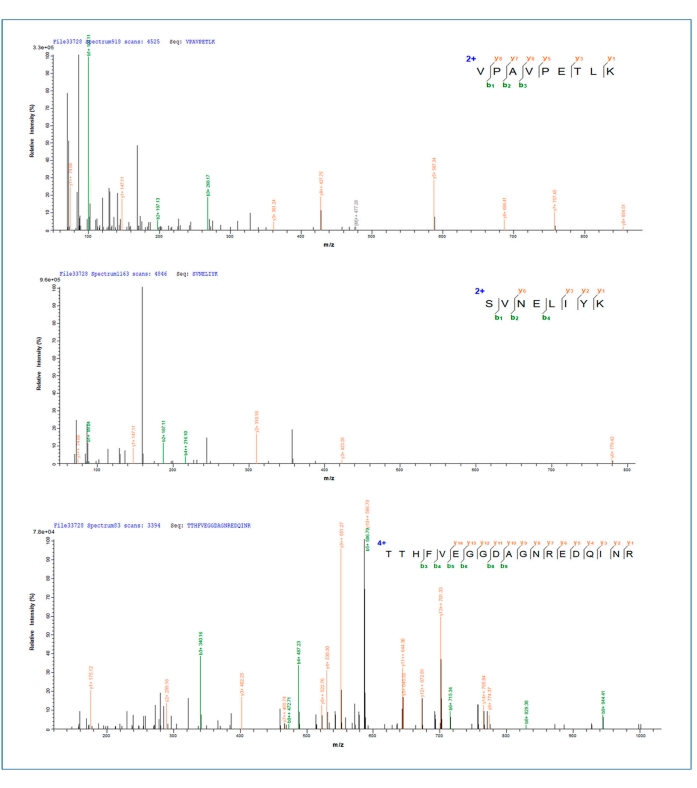

(c)

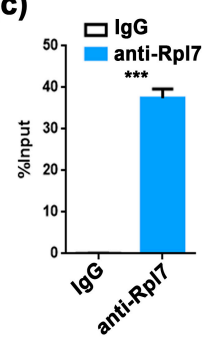

(d) 믈 circhipk2-NC
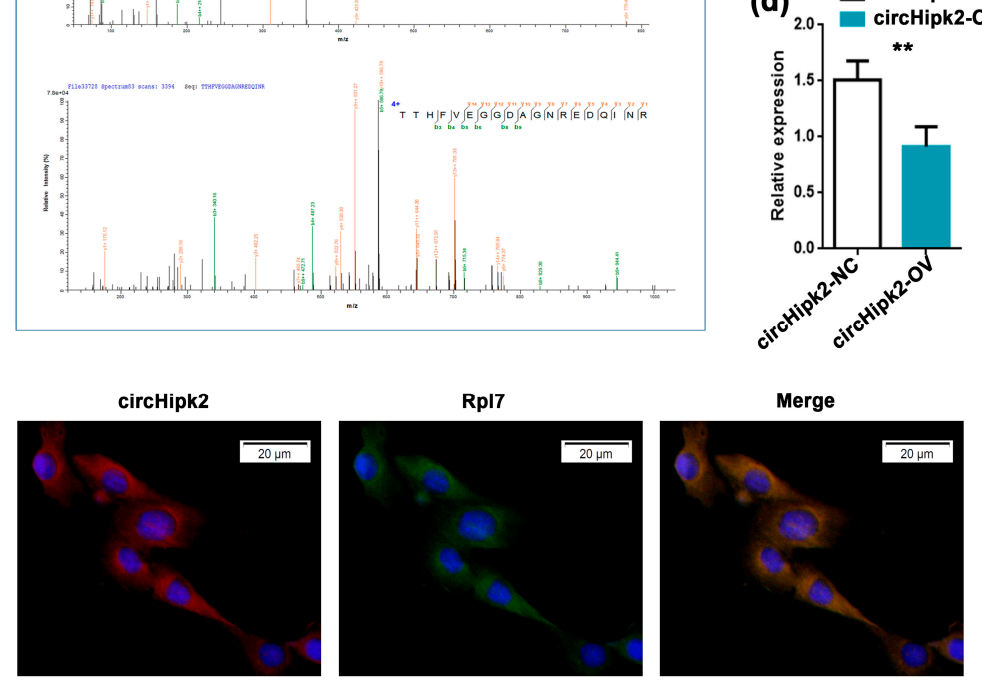

circHipk2 Rpl7

Figure 3. circHipk2 functions by binding to ribosomal protein Rpl7. (a) Schematic of $\lambda$ N-peptide-mediated capture of pLC5circHipk2-Flag from cellular lysates of overexpressing C2C12 myoblasts, and label-free mass spectrometric quantification. Experiments were performed in a pool of three biological replicates (quadruplicate measurements). (b) Western blotting of Rpl7 after $\lambda \mathrm{N}$-peptide-mediated pLC5-circHipk2-Flag capture in C2C12 myoblasts. (c) Fold enrichment of circHipk2 quantitated by RT-qPCR after the RIP assay with the Rpl7 antibody. IgG was used as the negative control. (d,e) The expression of Rpl7 was detected by RT-qPCR (d) and Western blotting (e) after transfection with circHipk2-OV and their negative controls in $\mathrm{C} 2 \mathrm{C} 12$ myoblasts. The error bars depict the mean \pm S.D. of samples from 3 measurements. ${ }^{* *} p<0.01$ and ${ }^{* * *} p<0.001$. (f) RNA-FISH assay was performed to determine Rpl7 and circHipk2 subcellular localization. Scale bar, $20 \mu \mathrm{m}$. 
Strong binding was determined for ribosomal protein L7 (Rpl7) (Figure 3a), and we further validated the interaction between circHipk2 and Rpl7 by pull-down and RNA immunoprecipitation (RIP) assays. As expected, $\lambda \mathrm{N}$-peptide-mediated pull-down of pLC5circHipk2-Flag followed by Western blotting validated that circHipk2 directly bound to Rpl7 protein (Figure 3b). Meanwhile, we found a significant enrichment of circHipk2 in the Rpl7 pull-down samples compared to the IgG negative controls (Figure 3c). In addition, overexpression of circHipk2 could significantly reduce the expression of Rpl7 at both mRNA (Figure 3d) and protein levels (Figure 3e). Then, we determined the subcellular localization of $R p l 7$ in C2C12 myoblasts. RNA-FISH showed that Rpl7 was mainly distributed in the cytoplasm, the same as circHipk2 (Figure 3f). Overall, these results indicated that circHipk2 directly bound to Rpl7 and inhibited its biogenesis.

\subsection{The Function Role of Rpl7 in Myogenesis Proliferation and Differentiation}

Previous studies suggested that Rpl7 could affect trophoblast differentiation, and is abnormally expressed in colon cancer and other diseases [31,32]. However, the functions of Rpl7 in myogenesis have not been reported. To investigate the role of Rpl7 in myoblast proliferation, we designed two siRNAs targeting Rpl7 (si-Rpl7-01 and si-Rpl7-02). After evaluating their silencing efficiencies, the siRNA si-Rpl7-01 was chosen for the next analysis. The expression of Ki67, PCNA, cyclin E1, and CDK4 were analyzed by RT-qPCR and Western blotting after transfection with si-Rpl7-01 in C2C12 cells. We found that the expression of these genes was significantly upregulated after Rpl7 knockdown (Figure 4a,b). Based on the EdU incorporation and CCK-8 assays, we observed that knockdown of Rpl7 significantly increased the activity of cell proliferation (Figure $4 \mathrm{c}, \mathrm{d}$ ).

Next, we investigated the role of Rpl7 on myoblast differentiation, and found that Rpl7 knockdown significantly upregulated the expression of differentiation markers (myogenin and MyHC1) at both mRNA (Figure 4e) and protein (Figure 4f) levels. As shown in Figure 4g, the knockdown of Rpl7 dramatically accelerated myotube formation when compared with the control group by immunostaining of $\mathrm{MyHC1}$. Taken together, these data indicated that Rpl7 promoted proliferation but had inhibitory effects on myoblast differentiation.

\subsection{Sp1 Modulates the Transcription of circHipk2}

To explore the mechanism that mediates the biogenesis of circHipk2 in myoblasts, we predicted the TFs that could potentially bind to the Hipk2 promoter via JASPAR (http:/ / jaspar.genereg.net, accessed on 8 August 2020). More than seven putative Sp1 binding sites in the promoter of Hipk2 were predicted (Figure 5a). Sp1 is a well-known activator of $M y o D$ and a suppressor of $C D K N 1 A$. It plays an important role in muscle cell proliferation and differentiation $[27,33,34]$. We cloned three continuous regions containing these binding sites (B1-B3) and constructed a series of luciferase reporter vectors (Figure 5b). The luciferase reporter assays showed that $S p 1$ significantly promoted the luciferase activity of the B3 promoter (Figure 5c). Meanwhile, overexpression of $S p 1$ significantly upregulated the expression of linear circHipk2 and Hipk2 (Figure 5d,e), implying that Sp1 may regulate the expression of Hipk2 and circHipk2. Moreover, chromatin immunoprecipitation (ChIP)qPCR analysis demonstrated that Sp1 could directly bind to the B3 of the Hipk2 promoter (Figure 5f). Therefore, these data illustrate that $S p 1$ is an upstream regulator of Hipk2 and directly affects the expression of Hipk2 and circHipk2 in myoblasts. 


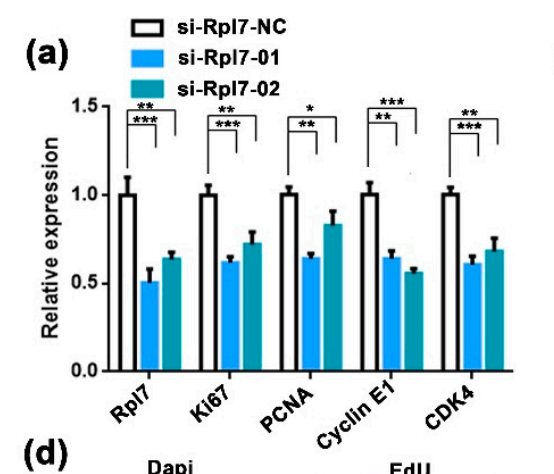

(d)
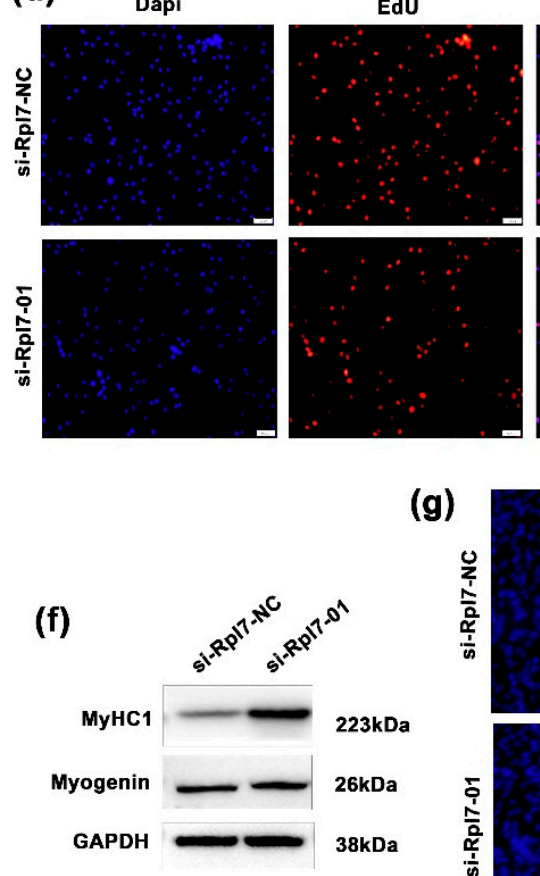

(g) (b)

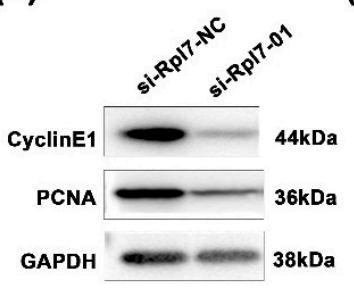

Merge
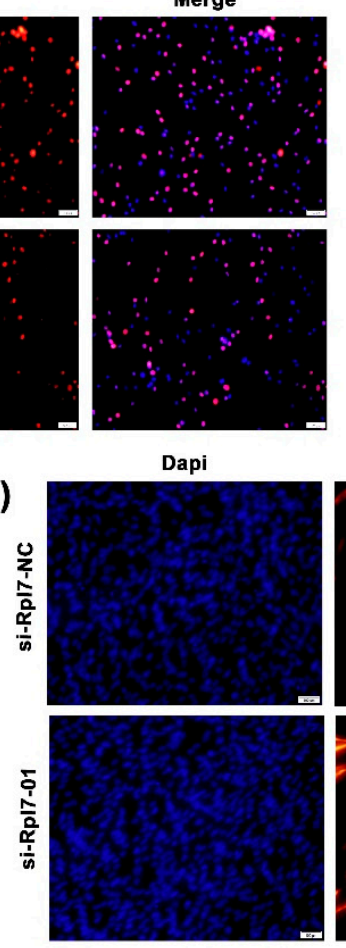

(c)

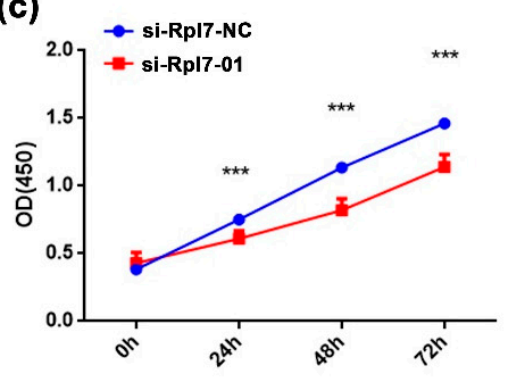

(e)
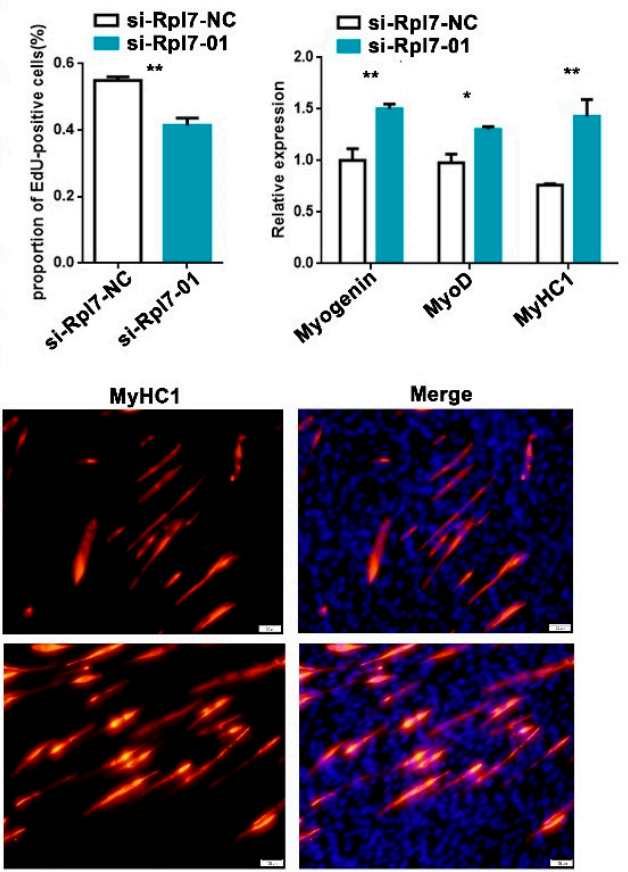

Figure 4. The role of $R p l 7$ in skeletal muscle proliferation and differentiation. $(\mathbf{a}, \mathbf{b})$ The expression of proliferation and cell cycle markers was quantitated by RT-qPCR (a) and Western blotting (b) in C2C12 myoblasts after transfection with si-Rpl7 or its control. Data are presented as the mean \pm S.D. $N=3$ per group. ${ }^{*} p<0.05,{ }^{* *} p<0.01$ and ${ }^{* * *} p<0.001$. (c) Cell proliferation was assessed using the CCK-8 assay after transfection with si-Rpl7-01 or its control. (d) EdU assay to assess cell proliferation after transfection with si-Rpl7-01 or si-Rpl7-NC in C2C12 myoblasts. Cell proliferation indices were assessed after treatment with EdU and counted using ImageJ. EdU staining (red) for positive cells; DAPI staining (blue) for cell nuclei. The scale bars represent $100 \mu \mathrm{m}$. (e,f) The mRNA and protein expression levels of myogenic differentiation markers myogenin and MyHC1 were detected by RT-qPCR (e) and Western blotting (f) after transfection with si-Rpl7-01 or si-Rpl7-NC in C2C12 myoblasts. (g) Immunofluorescence analysis of MyHC1 cells (red) after transfection with si-Rpl7-01 or its control in C2C12 myoblasts. The scale bars represent $100 \mu \mathrm{m}$. 
(a)

$\begin{array}{ll}\text { (a) } & \text { score } \\ \text { CCCCGCCTCG } & \\ \text { CCCCGCCGAC- } \\ \text { CCCCACCCTC- } \\ \text { CCCAGCCCCG- } \\ \text { CCCCGGCCCG- } \\ \text { ACCCTCCCAC- } \\ \text { GCCCTCCCCG- }\end{array}$

(d)

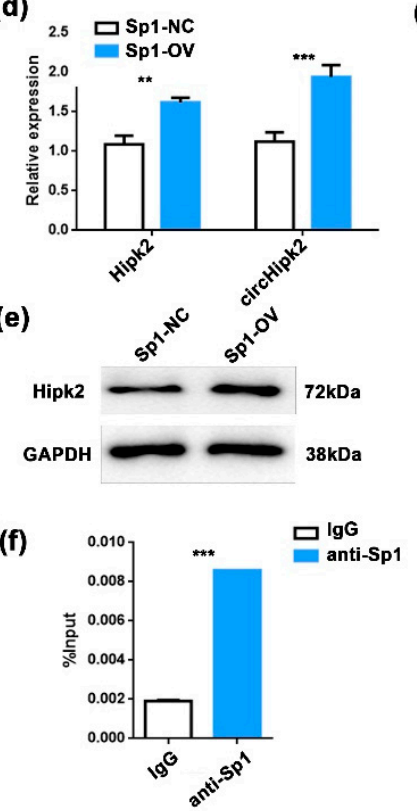

15

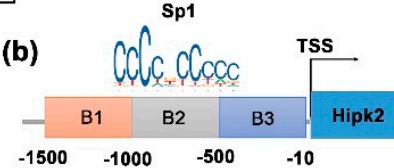

(g) (c)

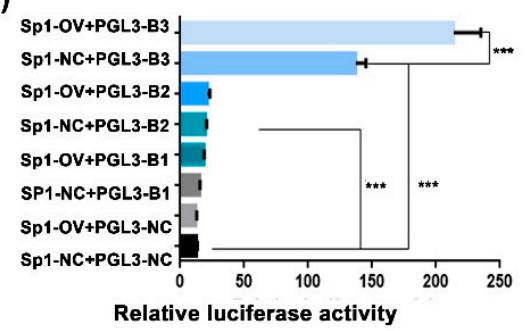

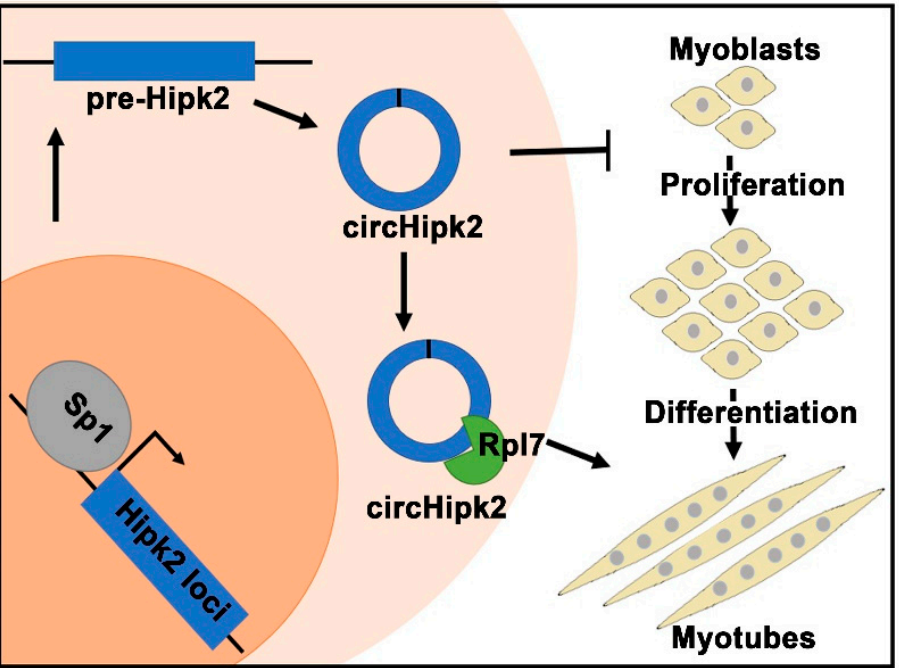

Figure 5. Sp1 modulates the transcription of circHipk2. (a) The score of enriched TF-binding motif Sp1 in the Hipk2 promoter. (b) Schematic illustration of putative binding regions of $S p 1$ in the Hipk2 promoter. (c) The relative luciferase activities were detected in HEK293T cells co-transfected with luciferase reporter plasmids containing putative Sp1-binding sites in the promoter sequence and overexpression plasmids of $S p 1$. (d,e) The expression levels of Hipk2 and circHipk2 were detected in C2C12 myoblasts after transfecting with Sp1-OV or Sp1-NC by RT-qPCR (d) and Western blotting (e). The error bars depict the mean \pm S.D of three replicates. ${ }^{* *} p<0.01,{ }^{* * *} p<0.001$. (f) The enrichment of Sp1 binding at Hipk2 promoter was detected by $\mathrm{ChIP}-\mathrm{qPCR}$ in $\mathrm{C} 2 \mathrm{C} 12$ myoblasts. $\mathrm{IgG}$ was used as a negative control. (g) A model of circHipk2 functions and regulation mechanism in myogenesis.

\section{Discussion}

It is well known that the multistep process of myogenesis is sophisticatedly controlled by the expression of myogenic genes, such as myogenic regulatory factors (MRFs) and paired box $(P A X)$ genes $[1,35,36]$. However, mounting studies suggest that myogenesis is also regulated by a variety of certain RNA types, including miRNAs, lncRNAs, and circRNAs $[7,37]$. In this study, we found that the circular RNA circHipk2 was significantly upregulated in C2C12 myoblast differentiation and mouse skeletal muscle regeneration, indicating that it had a potential effect in regulating skeletal muscle development. Further investigation demonstrated the anti-proliferation and pro-differentiation function of circHipk2 in myoblasts by acting as an Rpl7 protein sponge. The results highlight the functions and mechanism of circHipk2 in myogenesis.

The aberrant expression of circRNAs is also reported to be associated with muscular disease $[7,12,13]$. However, only a few of circRNAs have been functionally and mechanistically characterized in skeletal muscle. For instance, circFUT10 reduces proliferation and facilitates differentiation of myoblasts by sponging $m i R-133 a$ [38]. circFGFR 4 can regulate myogenesis by sponging miR-107 [39]. circTTN acts as a sponge of $m i R-432$ to facilitate the proliferation and differentiation of myoblasts via the IGF2/PI3K/AKT signaling pathway [40]. Our microarray studies suggested that circHipk2 was differentially expressed 
during myoblast differentiation in $\mathrm{C} 2 \mathrm{C} 12$ cells. Here, we demonstrated the function of circHipk2, repressing myoblast proliferation but promoting differentiation. These results uncover circHipk2 as a new regulator of skeletal muscle development. Autophagy and apoptosis also play important roles in myogenesis, upregulation of apoptosis increases autophagy, and autophagy promotes myoblasts catabolism, supporting the normal differentiation of myoblasts [41,42]. In a future study, the function of circHipk2 in autophagy and apoptosis should also be explored.

circRNAs modulate gene expression by various mechanisms, including functioning as miRNA sponges, RNA-binding protein (RBP) sponges, transcription regulators, and templates for translating peptides [37,43,44]. ciRS-7 (also known as CDR1as), the first miRNA sponge to be identified, is well known for sponging miR-7 [45]. ci-ankrd52 is directly associated with the chromatinized DNA at its host locus and stimulates the expression of the host genes from which it derives [46]. circ-ZNF609 is known to be associated with heavy polysomes, and produces a detectable endogenous protein in murine and human myoblasts [17,47]. circRNAs directly interact with many different RBPs to act as protein sponges [48,49]. circM $\mathrm{bl}$ harbors a binding site for $M b l$ and $M B N L 1$, to which the binding of $\mathrm{Mbl}$ (or MBNL1) facilitates the looping of the nascent RNA to promote circMbl biogenesis, and an autoregulatory circuit may exist [50]. circPABPN1 suppresses the translation of nuclear poly(A) binding protein 1 (PABPN1) by sequestering the RBP Hu-antigen R (HUR) [51]. However, the expression, function, and mechanism of circRNAs functioning as a protein sponge in myogenesis are largely unknown. $R p l 7$ is a coregulator of several nuclear receptors, which regulates protein expression in mammalian cells by tunable synthetic translational inhibition [31,32,52]. When functioning as a ribosomal protein, $R p l 7$ forms homodimers which interact with specific sites on poly(A) RNA and DNA and associates with the large ribosomal subunit as part of the translational machinery [52,53]. In this study, we identified circHipk2 acting as a binding protein sponge in myogenesis. circHipk2 inhibited myoblast proliferation and promotes differentiation by binding ribosomal protein Rpl7. Function studies suggested that Rpl7 promoted myoblast proliferation and inhibited differentiation by affecting ribosomal translation in all probability. Meanwhile, with a combination of bioinformatic tools [54-57], we predicted that circHipk2 contained an ORF coding 359aa, probably contained six high-confidence $\mathrm{m}^{6} \mathrm{~A}$ sites, and potential IRES sequences. Further studies are needed to explore the protein-coding potential of circHipk2.

The expression of circRNAs is also regulated by upstream transcription factors. It is reported that transcription factor Twist1 promoted circ-Cul2 transcription through binding to its promoter [58]. E2F1 and EIF4A3 could increase the expression level of circSEPT9 [59]. $S p 1$ is a zinc finger transcription factor that binds GC-rich DNA motifs to regulate thousands of genes, and is involved in many critical cellular functions, such as cell growth, differentiation, and apoptosis $[60,61]$. Recent studies suggested that $S p 1$ could function as a DNA methylation-related modulator and an activator of myogenic differentiation, and plays a critical role in skeletal muscle development [27,33]. In this study, we verified that $S p 1$ directly binds to the promoter of circHipk2 and promoted the expression of both Hipk 2 and circHipk2 in $\mathrm{C} 2 \mathrm{C} 12$ myoblasts. In addition to transcription factors, competing RNA pairings modulate the transcription of circRNAs. At the individual gene level, alternative circularization suggests that one gene locus can produce multiple circRNAs with mechanisms related to alternative back-splicing and alternative splicing site selection. For example, both the CAMSAP1 and CRKL locus could produce two major circRNA isoforms $[62,63]$. The circRNA microarray profiling suggested that the Hipk2 locus could produce an exonic circRNA and an intronic circRNA. However, detailed mechanisms in the regulatory process need to be further elucidated.

\section{Conclusions}

In summary, our data highlight that the Sp1-mediated circHipk2-Rpl7 axis regulates myogenesis (Figure 5g). Our study suggests that circHipk2 is a critical myogenesis regu- 
lator during skeletal muscle development, and provides a new insight to understand the mechanism of circRNAs in myogenesis.

Supplementary Materials: The following are available online at https:/ /www.mdpi.com/article/10 .3390/genes12050696/s1, Figure S1. The temporal expression patterns of Hipk2. Figure S2. Overexpression of circHipk2 prevents $\mathrm{C} 2 \mathrm{C} 12$ myoblast proliferation but promotes differentiation. Figure S3. Identification of circHipk2-binding proteins. Table S1. Information regarding the primers and siRNAs used in the present study. Table S2. Summary of pLC5-circHipk2-Flag binding proteins.

Author Contributions: Z.T. designed and managed the project. J.Y. performed the molecular experiments. Y.Y., X.F., and Y.T. collected biological samples. J.Y. and Y.Y. wrote the manuscript. Z.T. revised the manuscript. All authors have read and agreed to the published version of the manuscript.

Funding: This work was supported by the Basic and Applied Basic Research Foundation of Guangdong Province (2019B1515120059), the Key R\&D Programmes of Guangdong Province (2018B020203003), the National Natural Science Foundation of China (31830090), and the Agricultural Science and Technology Innovation Program (CAAS-ZDRW202006).

Institutional Review Board Statement: Not applicable.

Informed Consent Statement: Not applicable.

Data Availability Statement: Not applicable.

Conflicts of Interest: The authors declare no competing conflict of interest.

\section{References}

1. Charge, S.B.; Rudnicki, M.A. Cellular and molecular regulation of muscle regeneration. Physiol. Rev. 2004, 84, 209-238. [CrossRef] [PubMed]

2. Naidu, P.S.; Ludolph, D.C.; To, R.Q.; Hinterberger, T.J.; Konieczny, S.F. Myogenin and MEF2 function synergistically to activate the MRF4 promoter during myogenesis. Mol. Cell. Biol. 1995, 15, 2707-2718. [CrossRef]

3. Tajbakhsh, S. Skeletal muscle stem cells in developmental versus regenerative myogenesis. J. Intern. Med. 2009, 266, 372-389. [CrossRef] [PubMed]

4. Kim, J.H.; Jin, P.; Duan, R.; Chen, E.H. Mechanisms of myoblast fusion during muscle development. Curr. Opin. Genet. Dev. 2015, 32, 162-170. [CrossRef] [PubMed]

5. Günther, S.; Kim, J.; Kostin, S.; Lepper, C.; Fan, C.-M.; Braun, T. Myf5-Positive Satellite Cells Contribute to Pax7-Dependent Long-Term Maintenance of Adult Muscle Stem Cells. Cell Stem Cell 2013, 13, 590-601. [CrossRef] [PubMed]

6. Kassar-Duchossoy, L.; Gayraud-Morel, B.; Gomès, D.; Rocancourt, D.; Buckingham, M.; Shinin, V.; Tajbakhsh, S. Mrf4 determines skeletal muscle identity in Myf5:Myod double-mutant mice. Nat. Cell Biol. 2004, 431, 466-471. [CrossRef]

7. Chen, R.; Lei, S.; Jiang, T.; Zeng, J.; Zhou, S.; She, Y. Roles of lncRNAs and circRNAs in regulating skeletal muscle development. Acta Physiol. 2020, 228, e13356. [CrossRef]

8. Chen, L.L.; Yang, L. Regulation of circRNA biogenesis. RNA Biol. 2015, 12, 381-388. [CrossRef] [PubMed]

9. Chen, J.-F.; Mandel, E.M.; Thomson, J.M.; Wu, Q.; Callis, T.E.; Hammond, S.M.; Conlon, F.L.; Wang, D.-Z. The Role of MicroRNA-1 and MicroRNA-133 in Skeletal Muscle Proliferation and Differentiation. Nat. Genet. 2005, 38, 228-233. [CrossRef]

10. Yu, X.; Zhang, Y.; Li, T.; Ma, Z.; Jia, H.; Chen, Q.; Zhao, Y.; Zhai, L.; Zhong, R.; Li, C.; et al. Long non-coding RNA Linc-RAM enhances myogenic differentiation by interacting with MyoD. Nat. Commun. 2017, 8, 14016. [CrossRef]

11. Salzman, J.; Chen, R.E.; Olsen, M.N.; Wang, P.L.; Brown, P.O. Cell-Type Specific Features of Circular RNA Expression. PLoS Genet. 2013, 9, e1003777. [CrossRef]

12. Qu, S.; Yang, X.; Li, X.; Wang, J.; Gao, Y.; Shang, R.; Sun, W.; Dou, K.; Li, H. Circular RNA: A new star of noncoding RNAs. Cancer Lett. 2015, 365, 141-148. [CrossRef] [PubMed]

13. Greco, S.; Cardinali, B.; Falcone, G.; Martelli, F. Circular RNAs in Muscle Function and Disease. Int. J. Mol. Sci. 2018, 19, 3454. [CrossRef] [PubMed]

14. Wu, L.; Xia, J.; Yang, J.; Shi, Y.; Xia, H.; Xiang, X.; Yu, X. Circ-ZNF609 promotes migration of colorectal cancer by inhibiting Gli1 expression via microRNA-150. J. Buon 2018, 23, 1343-1349.

15. Wei, X.; Li, H.; Yang, J.; Hao, D.; Dong, D.; Huang, Y.; Lan, X.; Plath, M.; Lei, C.; Lin, F.; et al. Circular RNA profiling reveals an abundant circLMO7 that regulates myoblasts differentiation and survival by sponging miR-378a-3p. Cell Death Dis. 2017, 8, e3153. [CrossRef] [PubMed]

16. Shen, X.; Tang, J.; Jiang, R.; Wang, X.; Yang, Z.; Huang, Y.; Lan, X.; Lei, C.; Chen, H. CircRILPL1 promotes muscle proliferation and differentiation via binding miR-145 to activate IGF1R/PI3K/AKT pathway. Cell Death Dis. 2021, 12, 1-14. [CrossRef] 
17. Legnini, I.; Di Timoteo, G.; Rossi, F.; Morlando, M.; Briganti, F.; Sthandier, O.; Fatica, A.; Santini, T.; Andronache, A.; Wade, M.; et al. Circ-ZNF609 Is a Circular RNA that Can Be Translated and Functions in Myogenesis. Mol. Cell 2017, 66, 22-37.e9. [CrossRef]

18. Wu, W.; Ji, P.; Zhao, F. CircAtlas: An integrated resource of one million highly accurate circular RNAs from 1070 vertebrate transcriptomes. Genome Biol. 2020, 21, 1-14. [CrossRef]

19. Zhang, Y.; Huang, R.; Cheng, M.; Wang, L.; Chao, J.; Li, J.; Zheng, P.; Xie, P.; Zhang, Z.; Yao, H. Gut microbiota from NLRP3deficient mice ameliorates depressive-like behaviors by regulating astrocyte dysfunction via circHIPK2. Microbiome 2019, 7, 116. [CrossRef] [PubMed]

20. Huang, R.; Zhang, Y.; Han, B.; Bai, Y.; Zhou, R.; Gan, G.; Yao, H. Circular RNA HIPK2 regulates astrocyte activation via cooperation of autophagy and ER stress by targeting MIR124-2HG. Autophagy 2017, 13, 1722-1741. [CrossRef]

21. Cao, Z.; Xiao, Q.; Dai, X.; Zhou, Z.; Jiang, R.; Cheng, Y.; Chao, J. circHIPK2-mediated sigma-1R promotes endoplasmic reticulum stress in human pulmonary fibroblasts exposed to silica. Cell Death Dis. 2017, 8, 3212. [CrossRef] [PubMed]

22. Hattangadi, S.M.; Burke, K.A.; Lodish, H.F. Homeodomain-interacting protein kinase 2 plays an important role in normal terminal erythroid differentiation. Blood 2010, 115, 4853-4861. [CrossRef] [PubMed]

23. Ciarapica, R.; Methot, L.; Tang, Y.; Lo, R.; Dali, R.; Buscarlet, M.; Stifani, S. Prolyl isomerase Pin1 and protein kinase HIPK2 cooperate to promote cortical neurogenesis by suppressing Groucho/TLE:Hes1-mediated inhibition of neuronal differentiation. Cell Death Differ. 2014, 21, 321-332. [CrossRef] [PubMed]

24. Puca, R.; Nardinocchi, L.; Sacchi, A.; Rechavi, G.; Givol, D.; D’Orazi, G. HIPK2 modulates p53 activity towards pro-apoptotic transcription. Mol. Cancer 2009, 8, 85. [CrossRef]

25. Iacovelli, S.; Ciuffini, L.; Lazzari, C.; Bracaglia, G.; Rinaldo, C.; Prodosmo, A.; Bartolazzi, A.; Sacchi, A.; Soddu, S. HIPK2 is involved in cell proliferation and its suppression promotes growth arrest independently of DNA damage. Cell Prolif. 2009, 42, 373-384. [CrossRef]

26. De La Vega, L.; Hornung, J.; Kremmer, E.; Milanovic, M.; Schmitz, M.L. Homeodomain-interacting protein kinase 2-dependent repression of myogenic differentiation is relieved by its caspase-mediated cleavage. Nucleic Acids Res. 2013, 41, 5731-5745. [CrossRef] [PubMed]

27. Yang, Y.; Fan, X.; Yan, J.; Chen, M.; Zhu, M.; Tang, Y.; Liu, S.; Tang, Z. A comprehensive epigenome atlas reveals DNA methylation regulating skeletal muscle development. Nucleic Acids Res. 2021, 49, 1313-1329. [CrossRef] [PubMed]

28. Zhang, M.; Zhang, M.Z.; Wen, S.H.; Sun, Y.F.; Jiang, P.H.; Wang, L.L.; Guan, D.W. The distribution and time-dependent expression of HIPK2 during the repair of contused skeletal muscle in mice. Histol. Histopathol. 2019, 34, 745-753. [PubMed]

29. Stuart, A.C.; Gottesman, M.E.; Palmer, A.G., 3rd. The N-terminus is unstructured, but not dynamically disordered, in the complex between HK022 Nun protein and lambda-phage BoxB RNA hairpin. FEBS Lett. 2003, 553, 95-98. [CrossRef]

30. Holdt, L.M.; Stahringer, A.; Sass, K.; Pichler, G.; Kulak, N.A.; Wilfert, W.; Kohlmaier, A.; Herbst, A.; Northoff, B.H.; Nicolaou, A.; et al. Circular non-coding RNA ANRIL modulates ribosomal RNA maturation and atherosclerosis in humans. Nat. Commun. 2016, 7, 12429. [CrossRef]

31. Duncan, K.A.; Jiménez, P.; Carruth, L.L. The selective estrogen receptor- $\alpha$ coactivator, RPL7, and sexual differentiation of the songbird brain. Psychoneuroendocrinology 2009, 34 (Suppl. S1), S30-S38. [CrossRef] [PubMed]

32. Boleij, A.; Roelofs, R.; Msc, R.M.J.S.; Schülin, T.; Glaser, P.; Swinkels, D.W.; Kato, I.; Tjalsma, H. Increased exposure to bacterial antigen RpL7/L12 in early stage colorectal cancer patients. Cancer 2010, 116, 4014-4022. [CrossRef] [PubMed]

33. Yu, S.J.; Zheng, L.; Ladanyi, M.; Asa, S.L.; Ezzat, S. Sp1-Mediated Transcriptional Control of Fibroblast Growth Factor Receptor 4 in Sarcomas of Skeletal Muscle Lineage. Clin. Cancer Res. 2004, 10, 6750-6758. [CrossRef]

34. Irrcher, I.; Hood, D.A. Regulation of Egr-1, SRF, and Sp1 mRNA expression in contracting skeletal muscle cells. J. Appl. Physiol. 2004, 97, 2207-2213. [CrossRef]

35. White, R.B.; Biérinx, A.-S.; Gnocchi, V.F.; Zammit, P.S. Dynamics of muscle fibre growth during postnatal mouse development. BMC Dev. Biol. 2010, 10, 21. [CrossRef] [PubMed]

36. Moore, D.; Ferket, P.; Mozdziak, P. Early post-hatch fasting induces satellite cell self-renewal. Comp. Biochem. Physiol. Part A Mol. Integr. Physiol. 2005, 142, 331-339. [CrossRef] [PubMed]

37. Panda, A.C.; Grammatikakis, I.; Munk, R.; Gorospe, M.; Abdelmohsen, K. Emerging roles and context of circular RNAs. Wiley Interdiscip. Rev. RNA 2017, 8, e1386. [CrossRef]

38. Li, H.; Yang, J.; Wei, X.; Song, C.; Dong, D.; Huang, Y.; Lan, X.; Plath, M.; Lei, C.; Ma, Y.; et al. CircFUT10 reduces proliferation and facilitates differentiation of myoblasts by sponging miR-133a. J. Cell. Physiol. 2018, 233, 4643-4651. [CrossRef]

39. Li, H.; Wei, X.; Yang, J.; Dong, D.; Hao, D.; Huang, Y.; Lan, X.; Plath, M.; Lei, C.; Ma, Y.; et al. circFGFR4 Promotes Differentiation of Myoblasts via Binding miR-107 to Relieve Its Inhibition of Wnt3a. Mol. Ther. Nucleic Acids 2018, 11, 272-283. [CrossRef]

40. Wang, X.; Cao, X.; Dong, D.; Shen, X.; Cheng, J.; Jiang, R.; Chen, H. Circular RNA TTN Acts As a miR-432 Sponge to Facilitate Proliferation and Differentiation of Myoblasts via the IGF2/PI3K/AKT Signaling Pathway. Mol. Ther. Nucleic Acids 2019, 18, 966-980. [CrossRef]

41. Chen, Y.; Zhang, W.; Guo, X.; Ren, J.; Gao, A. The crosstalk between autophagy and apoptosis was mediated by phosphorylation of Bcl-2 and beclin1 in benzene-induced hematotoxicity. Cell Death Dis. 2019, 10, 1-15. [CrossRef]

42. Jiao, J.; Demontis, F. Skeletal muscle autophagy and its role in sarcopenia and organismal aging. Curr. Opin. Pharmacol. 2017, 34, 1-6. [CrossRef] [PubMed] 
43. Ai, H.; Fang, X.; Yang, B.; Huang, Z.; Chen, H.; Mao, L.; Zhang, F.; Zhang, L.; Cui, L.; He, W.; et al. Adaptation and possible ancient interspecies introgression in pigs identified by whole-genome sequencing. Nat. Genet. 2015, 47, 217-225. [CrossRef] [PubMed]

44. Papatsirou, M.; Artemaki, P.I.; Scorilas, A.; Kontos, C.K. The role of circular RNAs in therapy resistance of patients with solid tumors. Pers. Med. 2020, 17, 469-490. [CrossRef] [PubMed]

45. Zhou, X.; Jiang, L.; Fan, G.; Yang, H.; Wu, L.; Huang, Y.; Xu, N.; Li, J. Role of the ciRS-7/miR-7 axis in the regulation of proliferation, apoptosis and inflammation of chondrocytes induced by IL-1 $\beta$. Int. Immunopharmacol. 2019, 71, 233-240. [CrossRef]

46. Zhang, Y.; Zhang, X.-O.; Chen, T.; Xiang, J.-F.; Yin, Q.-F.; Xing, Y.-H.; Zhu, S.; Yang, L.; Chen, L.-L. Circular Intronic Long Noncoding RNAs. Mol. Cell 2013, 51, 792-806. [CrossRef]

47. Rossi, F.; Legnini, I.; Megiorni, F.; Colantoni, A.; Santini, T.; Morlando, M.; Di Timoteo, G.; Dattilo, D.; Dominici, C.; Bozzoni, I. Circ-ZNF609 regulates G1-S progression in rhabdomyosarcoma. Oncogene 2019, 38, 3843-3854. [CrossRef]

48. Li, H.; Li, K.; Lai, W.; Li, X.; Wang, H.; Yang, J.; Chu, S.; Wang, H.; Kang, C.; Qiu, Y. Comprehensive circular RNA profiles in plasma reveals that circular RNAs can be used as novel biomarkers for systemic lupus erythematosus. Clin. Chim. Acta 2018, 480, 17-25. [CrossRef]

49. Wang, J.; Ren, Q.; Hua, L.; Chen, J.; Zhang, J.; Bai, H.; Bai, X. Comprehensive Analysis of Differentially Expressed mRNA, lncRNA and circRNA and Their ceRNA Networks in the Longissimus Dorsi Muscle of Two Different Pig Breeds. Int. J. Mol. Sci. 2019, 20, 1107. [CrossRef]

50. Ashwal-Fluss, R.; Meyer, M.; Pamudurti, N.R.; Ivanov, A.; Bartok, O.; Hanan, M.; Kadener, S. circRNA Biogenesis Competes with Pre-mRNA Splicing. Mol. Cell 2014, 56, 55-66. [CrossRef]

51. Abdelmohsen, K.; Panda, A.; Munk, R.; Grammatikakis, I.; Dudekula, D.B.; De, S.; Kim, J.; Noh, J.H.; Kim, K.M.; Martindale, J.L.; et al. Identification of HuR target circular RNAs uncovers suppression of PABPN1 translation by CircPABPN1. RNA Biol. 2017, 14, 361-369. [CrossRef]

52. Linke, A.T.; Marchant, B.; Marsh, P.; Frampton, G.; Murphy, J.; Rose, M.L. Screening of a HUVEC cDNA library with transplantassociated coronary artery disease sera identifies RPL7 as a candidate autoantigen associated with this disease. Clin. Exp. Immunol. 2001, 126, 173-179. [CrossRef] [PubMed]

53. Russell, A.G.; Shutt, T.E.; Watkins, R.F.; Gray, M.W. An ancient spliceosomal intron in the ribosomal protein L7a gene (Rpl7a) of Giardia lamblia. BMC Evol. Biol. 2005, 5, 45. [CrossRef]

54. Wu, P.; Mo, Y.; Peng, M.; Tang, T.; Zhong, Y.; Deng, X.; Xiong, F.; Guo, C.; Wu, X.; Li, Y.; et al. Emerging role of tumor-related functional peptides encoded by lncRNA and circRNA. Mol. Cancer 2020, 19, 1-14. [CrossRef] [PubMed]

55. Min, X.J.; Butler, G.; Storms, R.; Tsang, A. OrfPredictor: Predicting protein-coding regions in EST-derived sequences. Nucleic Acids Res. 2005, 33, W677-W680. [CrossRef] [PubMed]

56. Mokrejš, M.; Vopálenský, V.; Kolenatý, O.; Mašek, T.; Feketová, Z.; Sekyrová, P.; Pospíšek, M. IRESite: The database of experimentally verified IRES structures (www.iresite.org). Nucleic Acids Res. 2006, 34, D125-D130. [CrossRef] [PubMed]

57. Zhou, Y.; Zeng, P.; Li, Y.-H.; Zhang, Z.; Cui, Q. SRAMP: Prediction of mammalian N6-methyladenosine (m6A) sites based on sequence-derived features. Nucleic Acids Res. 2016, 44, e91. [CrossRef]

58. Meng, J.; Chen, S.; Han, J.-X.; Qian, B.; Wang, X.-R.; Zhong, W.-L.; Qin, Y.; Zhang, H.; Gao, W.-F.; Lei, Y.-Y.; et al. Twist1 Regulates Vimentin through Cul2 Circular RNA to Promote EMT in Hepatocellular Carcinoma. Cancer Res. 2018, 78, 4150-4162. [CrossRef]

59. Zheng, X.; Huang, M.; Xing, L.; Yang, R.; Wang, X.; Jiang, R.; Zhang, L.; Chen, J. The circRNA circSEPT9 mediated by E2F1 and EIF4A3 facilitates the carcinogenesis and development of triple-negative breast cancer. Mol. Cancer 2020, 19, 1-22. [CrossRef]

60. Nylén, C.; Aoi, W.; Abdelmoez, A.M.; Lassiter, D.G.; Lundell, L.S.; Wallberg-Henriksson, H.; Naslund, E.; Pillon, N.J.; Krook, A. IL6 and LIF mRNA expression in skeletal muscle is regulated by AMPK and the transcription factors NFYC, ZBTB14, and SP1. Am. J. Physiol. Metab. 2018, 315, E995-E1004. [CrossRef]

61. Tan, N.Y.; Khachigian, L.M. Sp1 phosphorylation and its regulation of gene transcription. Mol. Cell Biol. 2009, $29,2483-2488$. [CrossRef] [PubMed]

62. Artemaki, P.I.; Scorilas, A.; Kontos, C.K. Circular RNAs: A New Piece in the Colorectal Cancer Puzzle. Cancers 2020, $12,2464$. [CrossRef] [PubMed]

63. Zhang, X.-O.; Wang, H.-B.; Zhang, Y.; Lu, X.; Chen, L.-L.; Yang, L. Complementary Sequence-Mediated Exon Circularization. Cell 2014, 159, 134-147. [CrossRef] [PubMed] 